ISSN 1392-3196 / e-ISSN 2335-8947

Zemdirbyste-Agriculture, vol. 107, No. 3 (2020), p. 235-242

DOI $10.13080 /$ z-a.2020.107.030

\title{
Leaching of potentially toxic elements from biochars intended for soil improvement
}

\author{
Jelena TITOVA ${ }^{1}$, Edita BALTRĖNAITĖ-GEDIENE ${ }^{1}$, Agnieszka MEDYŃSKA-JURASZEK ${ }^{2}$, \\ Eugenija BAKŠIENË $\dot{E}^{3}$ \\ ${ }^{1}$ Vilnius Gediminas Technical University, Research Institute of Environmental Protection \\ Saulètekio 11, Vilnius, Lithuania \\ E-mail: titovajelena1@gmail.com \\ ${ }^{2}$ Wrocław University of Environmental and Life Sciences, \\ Institute of Soil Science and Environmental Protection \\ Grunwaldzka 53, 50-357 Wrocław, Poland \\ ${ }^{3}$ Lithuanian Research Centre for Agriculture and Forestry, Vokè Branch \\ Žalioji 2, Vilnius, Lithuania
}

\begin{abstract}
The current study investigated the effects of feedstock type and pyrolysis temperature on the leaching of potentially toxic elements (PTEs) $(\mathrm{Cu}, \mathrm{Zn}, \mathrm{Cd}, \mathrm{Ni}, \mathrm{Cr}$ and $\mathrm{Pb})$ from the biochar. The aim was to find out, which type of biochar would be best suited for soil improvement. Five types of feedstock were used: sewage sludge compost (SSC) (1); the biomass of unfertilized (2) and fertilized with SSC (3) willow (Salix sp. cultivar 'Tora'); the biomass of unfertilized (4) and fertilized with SSC (5) perennial mugwort (Artemisia dubia Wall.). It was found that the leaching concentrations of PTEs were higher of mugwort-based biochar in comparison to willow-based biochar. However, in the eluates of mugwort-based biochar, the biggest part of PTEs was bound in complexes with dissolved organic carbon. This means that PTEs in the eluates of mugwort biochar were less mobile and less toxic to soil organisms. PTEs leached from the biochar produced at a temperature of $700^{\circ} \mathrm{C}$ also were mostly in complexes with dissolved organic carbon. The leaching concentrations of PTEs were higher of the biochar produced from plants fertilized with SSC in comparison to the biochar produced from unfertilized plants $(p<0.05)$.

It is difficult to predict how the process of leaching of PTEs from the biochar would take place if this biochar were to be introduced into the soil. There are many factors that can affect this. It was found that PTEs leaching concentrations of the biochar did not always depend directly on the total concentrations of PTEs in this biochar. However, it is likely that unfertilized plant-based biochar produced at $700^{\circ} \mathrm{C}$ temperature would be more suitable for soil improvement.
\end{abstract}

Key words: Artemisia dubia, heavy metals, potentially toxic elements, Salix, sewage sludge compost.

\section{Introduction}

The problem of soil depletion and degradation is becoming increasingly urgent all over the world. This problem is also encountered in Lithuania. Actually, unproductive and less favoured areas account for $10.5 \%$ (684305.31 ha) of the total land area of Lithuania (The productivity..., 2011; Land Fund of the Republic of Lithuania, http://zis.lt/wp-content/uploads/2017/04/ ZF 2017.pdf). There is a need to increase soil fertility in various ways, which can be as follows: no-till farming, crop rotation, liming and cultivation of perennial crops. Perennial energy grasses or short rotation energy plantations can also be grown (Njakou Djomo et al., 2015; Titova, Bakšienè, 2015; Bakšienè, Titova, 2018). In Lithuania, willow (Salix spp.) is grown predominantly in energy plantations (Sakalauskas et al., 2012). The cultivation of various energy crops reduces soil erosion and nutrient leaching (Demo et al., 2014). It also increases humus and organic carbon content as well as improves soil moisture regime (Dimitriou et al., 2012).

Another way of increasing soil fertility, which is increasingly explored, is the incorporation of biochar into the soil (Novotny et al., 2015; Tammeorg et al., 2017; Rasa et al., 2018), which is believed to improve soil structure and moisture regime (Laird et al., 2010; Rasa et al., 2018; Zhao et al., 2018). The incorporation of biochar into the soil decreases nutrient leaching (Laird, Rogovska, 2015; Haider et al., 2016), increases the population of soil microorganisms and their viability (Shareef, Zhao, 2017). Due to the usually high alkalinity of biochar itself $(\mathrm{pH} \geq 7)$, its incorporation into the soil decreases soil acidity (Chan et al., 2007; Novotny et al., 2015), which is very useful for it.

Please use the following format when citing the article:

Titova J., Baltrėnaitè-Gedienė E., Medyńska-Juraszek A., Bakšienė E. 2020. Leaching of potentially toxic elements from biochars intended for soil improvement. Zemdirbyste-Agriculture, 107 (3): 235-242. DOI 10.13080/z-a.2020.107.030 
One of the signs of soil degradation is low $\mathrm{pH}$. In addition, with increasing $\mathrm{pH}$, heavy metals (potentially toxic elements, PTEs) become less mobile (Liang et al., 2017) and less likely to leach into groundwater. Biochar also enriches the soil with stable carbon and at the same time increases the growth and yield of plants (Kammann et al., 2015; Frenkel et al., 2017). Biochar from energy plants can be used for soil improvement (Rasa et al., 2018).

Another important environmental problem is the utilization of sewage sludge (Kacprzak et al., 2017; Ozdemir et al., 2020). It is possible to produce biochar from sewage sludge or sewage sludge compost and incorporate it into the soil to improve its properties ( $\mathrm{Lu}$ et al., 2013; Van Wesenbeeck et al., 2014). However, such biochar should be used with caution, as it can contaminate the soil with PTEs (Van Wesenbeeck et al., 2014).

Another method of recycling sewage sludge is composting and using such compost to fertilize energy crops. Sewage sludge compost (SSC) contains useful elements (N, P, Ca, Mg, etc.) for plants (Wierzbowska et al., 2016; Kacprzak et al., 2017). Later, the biomass of energy crops can be used traditionally, such as burning to get energy. Alternatively, biochar can be produced from the biomass of energy plants (Nasr, 2020), and then such biochar can be incorporated into the soil to improve its properties.

In both cases of the incorporation of biochar in the soil there is a risk of PTEs entering the soil along with biochar. However, not only the total PTEs concentration in the biochar is important, but also what concentrations of PTEs can leach out from it. Biochar with the lowest concentrations of leached PTEs is best suited for soil improvement.

As it has already have mentioned, there are a lot of data in the literature (Lu et al., 2013; Novotny et al., 2015; Rasa et al., 2018) suggesting that the incorporation of biochar into the soil improves its properties. However, it is necessary to control the amounts of substances released into the environment, including soil.

Research is being carried out on PTEs leaching from biochar all over the world (Beesley, Marmiroli, 2011; Mancinelli et al., 2017). The most numerous are the studies related to PTEs leaching from sewage sludge biochar and biochar derived from its compost (Agrafioti et al., 2013; Pečkytè, Baltrènaite, 2015). However, the research carried out on the leaching of PTEs from the biochar produced from willow (Salix sp.) and mugwort (Artemisia dubia Wall.) biomass is new. In addition, these plants are a promising biochar feedstock as they grow quickly and produce large amounts of biomass required for biochar production (Mola-Yudego, GonzálesOlabarria, 2010; Titova, Bakšienè, 2015). Furthermore, the wooden vascular structure of Artemisia spp. easily forms pore channels (Song et al., 2019). Therefore, it is appropriate to pyrolyze Artemisia spp. biomass into biochar. In addition, mugwort and willow biomass contains high levels of lignin and cellulose (Kryževičienè et al., 2010; Krzyżaniak et al., 2014; Kadžiulienè et al., 2017). This is useful for biochar production and use.

There is currently no legal framework in place for controlling the use of biochar in agriculture in Lithuania. In other European Union (EU) countries, the legal framework governing the use of biochar is diverse. However, several documents exist throughout the EU listing recommended physical and chemical limit values for biochar. These include the European Biochar Certificate (EBC, 2012), International Biochar Initiative (IBI, 2014), Biochar Standards, Biochar Quality Mandate and others. All these documents promote responsible use of biochar and monitor the indicators most harmful to soil. Among the proposed parameters for observation are the potentially toxic elements $\mathrm{Cr}, \mathrm{Cd}$, $\mathrm{Ni}, \mathrm{Cu}, \mathrm{Pb}$ and $\mathrm{Zn}$. However, even the aforementioned common EU documents offer limit values only for the total concentrations of these elements. They do not yet estimate the amounts of such PTEs that could be leached from biochar if incorporated into the soil. That information is very important from an environmental point of view. There is a lack of data on the potential leaching of PTEs from biochar, and the results of current experiment to be useful in developing threshold values for PTEs leaching concentrations are expected.

The main purpose of the study described in this paper is to assess how the type of feedstock and pyrolysis temperature affect PTEs $(\mathrm{Cu}, \mathrm{Zn}, \mathrm{Cd}, \mathrm{Ni}, \mathrm{Cr}$ and $\mathrm{Pb}$ ) leaching from biochar and their forms in the filtrate. This information is very important to find out, which type of biochar is best suited for soil improvement.

\section{Materials and methods}

Selection of biochar feedstocks and biochar production. The biochar was produced from five types of feedstock: sewage sludge compost (SSC) (1); the biomass of unfertilized (2) and fertilized with SSC (3) willow (Salix sp. cultivar 'Tora'); the biomass of unfertilized (4) and fertilized with SSC (5) perennial mugwort (Artemisia dubia Wall.).

Previous studies of Titova (2016) showed that the mentioned plants uptake potentially toxic elements (PTEs) from soil particularly intensively. Dimitriou et al. (2012), Jama-Rodzeńska and Nowak (2012) and Grignet et al. (2020) also found that willow actively accumulates some PTEs from the soil. In this way, the cultivation of willow and mugwort for the production of biochar would reduce the negative impact of sewage sludge compost on the soil. This impact would inevitably occur if the plants were fertilized with SSC. These plants grow very well under temperate climate, including Lithuania (Kryževičienè et al., 2010; Kadžiulienè et al., 2017; Bakšienè, Titova, 2018). This means that a lot of feedstock can be obtained easily.

Sewage sludge compost was provided by the company UAB "Biastra Plius" (Lithuania) in the spring of 2018. Plant biomass was provided by Voke Branch of the Lithuanian Research Centre for Agriculture and Forestry. In this institution, plants were grown on a light textured soil sandy loam Haplic Luvisol (WRB, 2014) in the climatic zone of south-eastern Lithuania $\left(54^{\circ} 37^{\prime} \mathrm{N}, 25^{\circ} 06^{\prime} \mathrm{E}\right)$.

Willow had been grown for 13 years since 2005. Mugwort had been grown for 6 years since 2012 . Willow was fertilized with SSC twice: 1) in the spring of the $8^{\text {th }}$ year of growing with $20 \mathrm{t} \mathrm{ha}^{-1}$ of SSC dry matter (DM), and 2) in the spring of the $12^{\text {th }}$ year of growing with $110 \mathrm{t} \mathrm{ha}^{-1}$ of SSC DM. Mugwort was also fertilized with SSC twice: 1) before planting, in the spring of 2012 with $80 \mathrm{t} \mathrm{ha}^{-1}$ of SSC DM, and 2) in the spring of the $5^{\text {th }}$ year of growing with $110 \mathrm{tha}^{-1}$ of SSC DM. The willow biomass was harvested in the spring of the $2^{\text {nd }}$ year, $8^{\text {th }}$ year and $12^{\text {th }}$ year of growing. The mugwort biomass was harvested every autumn. For biochar production biomass yield of 2017 was used.

Before the biochar production, the plants were crushed. Then SSC and plants were oven-dried to a constant weight at $105^{\circ} \mathrm{C}$. Feedstocks were pyrolyzed in a muffle furnace SNOL 30/1100 E5CK-T (SNOL, Lithuania) under limited oxygen conditions. The heating rate was $10^{\circ} \mathrm{C} \mathrm{min}^{-1}$ (Lu et al., 2013).

In the described experiment, biochar was produced at $450^{\circ} \mathrm{C}$ and $700^{\circ} \mathrm{C}$ temperatures. The residence time in the pyrolysis was 2 hours. Pyrolysis temperatures (low $450^{\circ} \mathrm{C}$ and high $700^{\circ} \mathrm{C}$ ) were chosen to produce biochars with different properties. There is evidence in the literature (Lu et al., 2013; Gusiatin et al., 2016; Zhao et al., 2018) that pyrolysis temperature greatly affects the physicochemical properties of biochar. A total of ten types of biochar were produced and investigated.

Physical and chemical properties of biochar. Cation exchange capacity (CEC) of biochar was determined according to the modified method described by Munera-Echeverri et al. (2018). The method modifies 
the existing ammonium acetate $\left(\mathrm{NH}_{4} \mathrm{OAc}\right)$ technique $(\mathrm{pH}$ 7), where ammonium $\left(\mathrm{NH}^{4+}\right)$ is displaced by potassium chloride $(\mathrm{KCl})$, following removal of excess $\mathrm{NH}_{4} \mathrm{OAc}$ with isopropanol, in batch mode. The modified CEC method consists of three main stages: 1) biochar pretreatment and sample acidity $(\mathrm{pH})$ adjustment to $\mathrm{pH} 7.0$, 2) extraction of exchangeable cations with $1 \mathrm{M} \mathrm{NH}_{4} \mathrm{OAc}$ at $\mathrm{pH} 7.0$, and 3) removal of excess $\mathrm{NH}_{4} \mathrm{OAc}$ with isopropanol and subsequent $\mathrm{NH}^{4+}$ extraction with $\mathrm{KCl}$. The supernatants were analysed for exchangeable base cations $\left(\mathrm{Ca}^{2+}, \mathrm{Mg}^{2+}, \mathrm{Na}^{+}\right.$and $\left.\mathrm{K}^{+}\right)$by a microwave plasmaatomic emission spectrometer $4200 \mathrm{MP}-\mathrm{AES}$ (Agilent Technologies, USA). Ammonia was analysed with Nessler reagent colorimetrically on a spectrophotometer UV-VIS Cary 60 (Agilent Technologies, USA) at $\lambda=640$ nm. CEC was calculated as a sum of $\mathrm{Ca}^{2+}, \mathrm{Mg}^{2+}, \mathrm{Na}^{+}, \mathrm{K}^{+}$, and $\mathrm{NH}_{4}^{+}$(Munera-Echeverri et al., 2018).

Hydrophobicity of biochar was investigated using a water drop penetration time test (Doerr, 1998; Usevičiūtè, Baltrènaité, 2019). Five grams of crushed homogenized biochar were placed on flat glass plates. Then, using a pipette, 5 drops of deionized water were placed on the surface of the biochar. Using a stop-watch, water drops (all 5 drops) penetration time was recorded. The following categories of hydrophobicity (time) were used (Doerr, 1998): 1) strongly hydrophilic $-<5 \mathrm{~s}, 2$ ) hydrophilic $-5-10 \mathrm{~s}, 3)$ slightly hydrophilic - 10-30 s, 4) slightly hydrophobic - 30-60 s, 5) moderately hydrophobic $-60-180 \mathrm{~s}, 6$ ) hydrophobic $180-300 \mathrm{~s}, 7$ ) strongly hydrophobic $-300-600 \mathrm{~s}, 8$ ) very strongly hydrophobic - 600-3600 s and 9) extremely hydrophobic $->3600 \mathrm{~s}$.

Potentially toxic elements (PTEs) leaching experiment was performed in the laboratory of Research Institute of Environmental Protection, Vilnius Gediminas Technical University. In order to assess the potential leaching of PTEs $(\mathrm{Cd}, \mathrm{Pb}, \mathrm{Cr}, \mathrm{Ni}, \mathrm{Zn}$ and $\mathrm{Cu}$ ) from the biochar to the soil, the up-flow percolation leaching test according to standard BS EN 14405:2017 (Characterization of waste. Leaching behaviour test. Up-flow percolation test (under specific condition) was applied. Ten types of biochar were investigated; two replicates were used. Columns $5 \mathrm{~cm}$ in diameter and $30 \mathrm{~cm}$ in height were used for the experiment (Pečkyte, Baltrènaite, 2015).

The scheme of leaching test equipment (Pečkytè, Baltrènaitè, 2015; Mancinelli et al., 2016) is shown in Figure 1.

The bottom section of each column was equipped with two filters. The biochar was crushed and then dried to a constant weight. A load of $100 \mathrm{~g}$ of such biochar was added to each column. Then the columns were saturated with water by hydrostatic pressure. The water-saturated biochar was left for 3 days to balance the system. Seven eluates were then collected at a constant rate. Each eluate was collected into a separate bottle. The volumes of eluates (L) were different: 1) $0.01,2$ ) $0.01,3) 0.03$, 4) $0.05,5) 0.1,6) 0.3$ and 7) 0.5 . They were calculated according to the procedure described in standard BS EN 14405:2017. They depended on the mass $(\mathrm{kg})$ and number of eluates used. The time required to collect each eluate was also recorded during the experiment.

The acidity $(\mathrm{pH})$ of all eluates was then measured using a $\mathrm{pH}$ meter Mettler Toledo SevenMulti (Mettler Toledo, USA); then the eluates were filtered. PTEs concentrations (mg L $\left.\mathrm{L}^{-1}\right)$ and dissolved organic carbon (DOC) $\left(\mathrm{mg} \mathrm{L}^{-1}\right)$ were analyzed in eluates. Concentrations of PTEs were determined by atomic absorption spectroscopy using a spectrophotometer Buck Scientific 210 VGP (Buck Scientific, USA) equipped with air-acetylene flame (FAAS) or using graphite furnace atomic absorption spectroscopy (GFAAS). DOC was determined using a Shimadzu VCSH-TOC Analyzer with ASI-V Auto Sampler System (Japan). The results of the analyses were needed to model the forms of PTEs in the eluates. The concentrations of PTEs were subsequently converted to $\mathrm{mg} \mathrm{kg}^{-1}$ and \% for further analysis. Leaching

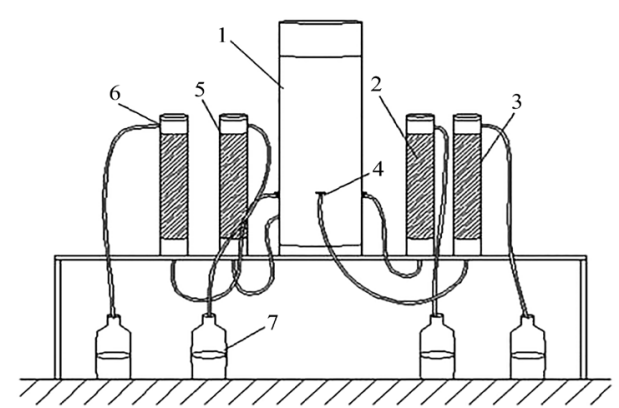

1 - deionized water, 2 - biochar, 3 - column, 4 - water inlet, 5 - layer of inert material, 6 - eluate outflow, 7 - eluate collection bottles

\section{Figure 1. The scheme of leaching test equipment}

concentrations of PTEs in percent were calculated as a percentage of PTEs total concentrations in biochar (Agrafioti et al., 2013).

WHAM modeling. Modeling of PTEs forms in eluates was performed using the Windermere Humic Aqueous Model (WHAM7) for waters (Tipping et al., 2011; Mancinelli et al., 2017). WHAM7 simulates the chemical processes that occur when metals enter soil and water systems. This model is very important for understanding how pollution can affect the environment and how PTEs bind to humic substances. WHAM7 can be used to predict the activity of free metal ions. It is possible to predict what part of PTEs will be in a free ion form in the eluates and what part of PTEs will be bound in complexes with DOC. Input data in model WHAM7 were: 1) PTEs concentrations $\left(\mathrm{mg} \mathrm{L}^{-1}\right)$ in biochar eluates, 2) $\mathrm{pH}$ of biochar eluates and 3 ) DOC concentrations $\left(\mathrm{mg} \mathrm{L}^{-1}\right)$ in biochar eluates. The temperature during the leaching experiment was $25^{\circ} \mathrm{C}$.

Statistical analysis. Each parameter was tested in 2-3 repetitions. Reference materials were also used: the European Reference Material ERM ${ }^{\circledR}-C D 100$ "Trace elements and pentachlorophenol (PCP) in wood" (https://rrr.bam.de/RRR/Content/EN/Downloads/RMCertificates/RM-cert-environment/erm cd100e.pdf? blob=publicationFile) and Sewage Sludge Certified Reference Material LGC6181 (https://www.lgcstandards. com/FR/en/Sewage-sludge-Extractable-metals/p/ LGC6181\#multianalytetable). The significant differences between the values of parameters of various biochar types were determined using the two-way analysis of variance (ANOVA) for Excel 2000, version 2.2 (Microsoft Corp., USA). Fisher test was used for comparison of data. Significant differences were observed at the $95 \%$ probability level. Standard errors were calculated.

\section{Results and discussion}

Leaching of potentially toxic elements (PTEs)

from biochar. Leaching experiment was carried out with all 10 types of biochar. Having estimated the lead $(\mathrm{Pb})$ leaching from various types of biochar during the experiment (total $\mathrm{Pb}$ concentration in all 7 eluate fractions, $\mathrm{mg} \mathrm{kg}^{-1}$ ), it was shown that $\mathrm{Pb}$ leaching from SSC biochar was 9 times lower than that from plant-based biochar $(p<0.05)$ (Fig. 2). Though Pb total concentrations were around 11 times higher in SSC biochar than in the plant-based biochar, it could have been expected that $\mathrm{Pb}$ leaching would be equally higher in SSC biochar.

It was found that $\mathrm{Pb}$ leaching was lower from willow-based biochar in comparison to mugwort-based biochar $(p<0.05)$. Pb leaching was higher for biochar produced from the biomass of plants fertilized with SSC in comparison to biochar produced from unfertilized plant biomass $(p<0.05)$. Pb leaching was higher from willow-based biochar produced at $700^{\circ} \mathrm{C}$ compared to 
that from willow-based biochar produced at $450^{\circ} \mathrm{C}(p<$ $0.05)$. The lowest $\mathrm{Pb}$ leaching was observed from SSC biochar $\left(0.037-0.055 \mathrm{mg} \mathrm{kg}^{-1} ; 450^{\circ} \mathrm{C}\right.$ and $\left.700^{\circ} \mathrm{C}\right)$ and from unfertilized willow-based biochar $\left(0.032 \mathrm{mg} \mathrm{kg}^{-1}\right.$; $450^{\circ} \mathrm{C}$ ) (Fig. 2).
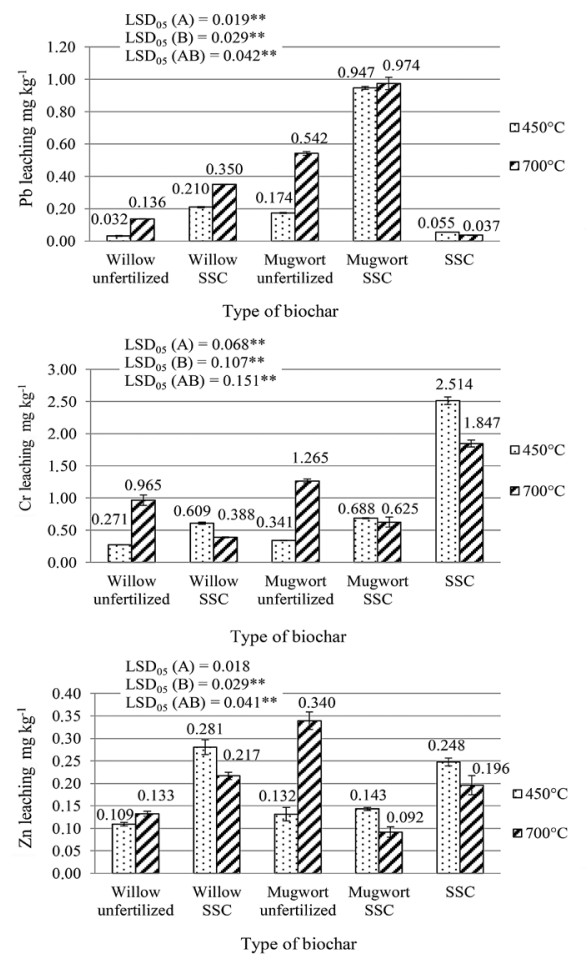

$\mathrm{LSD}_{05}$ - least significant difference at the 0.05 probability level; $\mathrm{n}=2$; mean value $\pm \mathrm{SE} ; \mathrm{SSC}-$ sewage sludge compost

Figure 2. Leaching of potentially toxic elements (PTEs) from biochar

$0.85 \mathrm{mg} \mathrm{kg}^{-1}(p<0.05)$. Ni leaching concentration of biochar produced from SSC at $700^{\circ} \mathrm{C}$ was similar or only 1.3 times higher than that of plant-based biochar. This demonstrates that the concentrations of PTEs that can be leached from biochar are not necessarily directly dependent on the total concentrations of the said elements in biochar. Agrafioti et al. (2013) studied Ni leaching from sewage sludge biochar (pyrolysis was performed at $300^{\circ} \mathrm{C}$ ). They also reported very low Ni leaching average concentration $-0.14 \mathrm{mg} \mathrm{kg}^{-1}(0.6 \%)$. The current study showed that just like in the case with $\mathrm{Pb}$, the leaching percentage of $\mathrm{Ni}$ was significantly lower $(p<0.05)$ in SSC biochar (1.44-2.22\%) in comparison to plant-based biochar (22.4-46.6\%) (Fig. 3).

A single trend showing how Ni leaching depends on the species of plant used to produce biochar could not be identified. In many cases, Ni leaching was higher from biochar produced from plants fertilized with SSC in comparison to biochar produced from unfertilized plants $(p<0.05)$. Based on these results, it can be concluded that unfertilized plant-based biochar would be more suitable to be incorporated into the soil. It was also found that $\mathrm{Ni}$ leaching concentration of SSC biochar produced at $700^{\circ} \mathrm{C}$ was statistically higher in comparison to SSC biochar produced at a lower $\left(450^{\circ} \mathrm{C}\right)$ temperature $(p<0.05)$.-

Contrary to $\mathrm{Pb}$ and $\mathrm{Ni}$, the leaching of chromium (Cr) was 1.5 to 9.3 times higher from SSC biochar (1.85$\left.2.51 \mathrm{mg} \mathrm{kg}^{-1}\right)$ in comparison to plant-based biochar $(0.27-$ $1.27 \mathrm{mg} \mathrm{kg}^{-1}$ ) (Fig. 2). However, the total concentration of Cr was as many as 52 times higher in SSC biochar than in plant-based biochar. With the initial $\mathrm{Cr}$ concentrations in plant-based biochar being very low $\left(0.78-3.35 \mathrm{mg} \mathrm{kg}^{-1}\right)$, the resulting leaching percentage of this element from the mentioned biochar was very high. It amounted to as much as $12.5 \%$ to $56.8 \%$. Leaching concentrations of SSC biochar was only from $1.7 \%$ to $2.7 \%$ (Fig. 3). Agrafioti et al. (2013) reported that $\mathrm{Cr}$ leaching concentration of

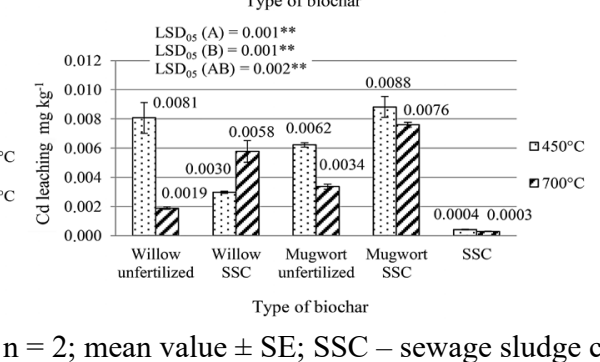

SSC biochar contained approximately 15 times higher nickel (Ni) concentrations than plantbased biochar $(p<0.05)$. Regardless of this, SSC biochar produced at $450^{\circ} \mathrm{C}$ had the lowest Ni leaching concentration out of all investigated biochar types, i.e.
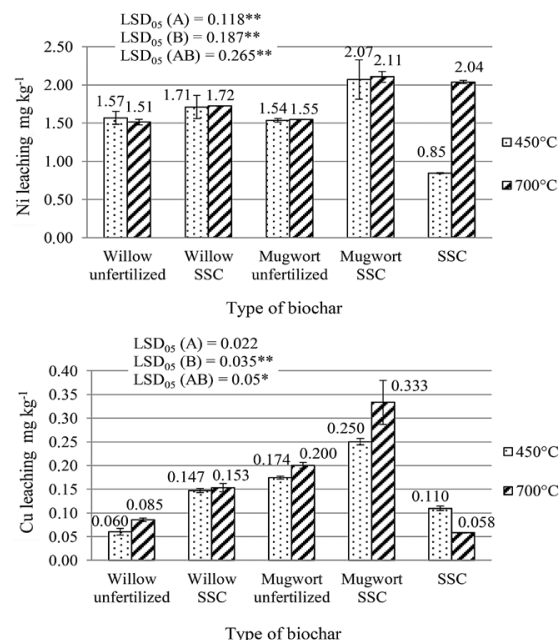

sewage sludge biochar (pyrolysis at $300^{\circ} \mathrm{C}$ ) was $0.5 \%$ $\left(0.11 \mathrm{mg} \mathrm{kg}^{-1}\right)$. Pečkyte and Baltrènaite (2015) found that $\mathrm{Cr}$ leaching concentration of biochar of paper mill sludge (pyrolysis at $450^{\circ} \mathrm{C}$ and $600^{\circ} \mathrm{C}$ ) was $0.00-0.26 \%$ and $\mathrm{Cr}$ leaching concentration of leather sludge biochar $-0.23-$ $0.47 \%$. It was also found that $\mathrm{Cr}$ leaching was lower from willow-based biochar in comparison to mugwort-based biochar. However, a significant difference $(p<0.05)$ was observed only in the case of the biochar produced at $700^{\circ} \mathrm{C}$ (Fig. 2).

The experiment also evaluated the effect of the fertilization of plants with SSC on the leaching of $\mathrm{Cr}$ $\left(\mathrm{mg} \mathrm{kg}^{-1}\right)$ from the biochar made of these plants. It was found that fertilization increased $\mathrm{Cr}$ leaching when the pyrolysis temperature was $450^{\circ} \mathrm{C}$ and decreased leaching when it was $700^{\circ} \mathrm{C}(p<0.05)$. No single trend showing the impact of pyrolysis temperature on the $\mathrm{Cr}$ leaching from the biochar was found. The results showed that the lowest leaching of $\mathrm{Cr}$ was observed from biochar produced at a pyrolysis temperature of $450^{\circ} \mathrm{C}$ from unfertilized willow and unfertilized mugwort $(p<0.05)$.

The study found that the average total concentration of copper $(\mathrm{Cu})$ in SSC biochar was approximately 15 times higher than that in plant-based biochar. Regardless of this, $\mathrm{Cu}$ leaching from SSC biochar $\left(0.084 \mathrm{mg} \mathrm{kg}^{-1}\right)$ was twice lower $(p<0.05)$ than in the case of plant-based biochar $\left(0.175 \mathrm{mg} \mathrm{kg}^{-1}\right)$ (Fig. 2). As a percentage, $\mathrm{Cu}$ leaching from SSC biochar $(0.053 \%$ on average) was also significantly lower $(p<0.05)$ than from plant-based biochar (1.65\% on average) (Fig. 3$)$. Beesley et al. (2010) noticed that leaching of $\mathrm{Cu}$, first of all, was influenced by the concentration of DOC in the biochar. However, the previous studies of the authors (Titova, Baltrènaitè-Gedienè, 2020; in press) showed that average DOC concentration in SSC biochar was two times lower than in plant biochar. 


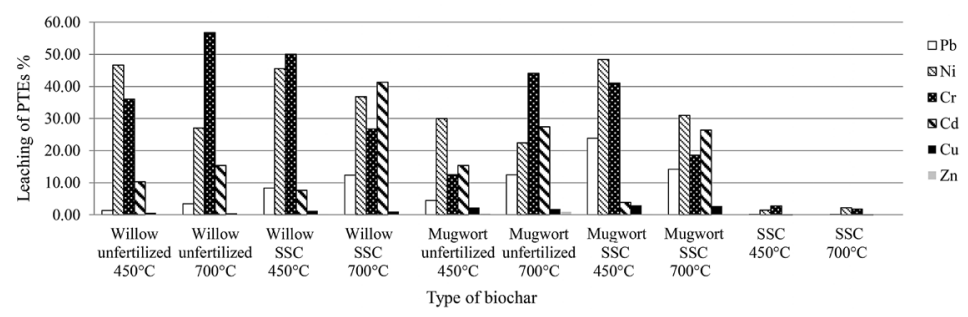

SSC - sewage sludge compost

Figure 3. Leaching percentage of potentially toxic elements (PTEs) from biochar

The current study showed that $\mathrm{Cu}$ leaching concentration was significantly lower $(p<0.05)$ of willow-based biochar than of mugwort-based biochar. In addition, $\mathrm{Cu}$ leaching was statistically lower $(p<0.05)$ from the biochar based on unfertilized plants in comparison to biochar based on plants fertilized with SSC (Fig. 2). The pyrolysis temperature of biochar did not have any significant effect $(p<0.05)$ on $\mathrm{Cu}$ leaching from this biochar. The lowest $\mathrm{Cu}$ leaching concentration was observed of SSC (pyrolysis at $700^{\circ} \mathrm{C}$ ) and of unfertilized willow-based (pyrolysis at $450^{\circ} \mathrm{C}$ and $\left.700^{\circ} \mathrm{C}\right)$ biochar $(p<0.05)$.

In the tested SSC biochar, zinc (Zn) concentration was on average 12 times higher than in plant-based biochar. Therefore, for SSC biochar, the Zn leaching percentage (from the initial $\mathrm{Zn}$ concentration in biochar) was as many as 14 times lower (only $0.012-0.013 \%$ ) than that for plant-based biochar (Fig. 3). However, when estimating the concentration in $\mathrm{mg} \mathrm{kg}^{-1}$, Zn leaching from SSC biochar was on average only 1.2 times higher than from plant-based biochar. Such a low level of leaching of $\mathrm{Zn}$ from SSC biochar could be explained by its high $\mathrm{pH}$. Beesley et al. (2010) confirmed this tendency. Pečkyte and Baltrénaite (2015) also reported that Zn leaching concentration from the biochar of paper mill sludge and from leather sludge biochar (pyrolysis at $450^{\circ} \mathrm{C}$ and $600^{\circ} \mathrm{C}$ ) was only $0.12-0.44 \%$. Of SSC-fertilized willowbased biochar, Zn leaching concentration was higher than in the case of SSC-fertilized mugwort-based biochar $(p<0.05)$ (Fig. 2). The fertilization of willows with SSC increased $\mathrm{Zn}$ leaching from the biochar produced from the biomass of these plants $(p<0.05)$. The increase in pyrolysis temperature reduced $\mathrm{Zn}$ leaching from SSC biochar and from biochar produced from SSC-fertilized willow and mugwort $(p<0.05)$. The lowest $\mathrm{Zn}$ leaching concentrations were observed of unfertilized willow-based and SSC-fertilized mugwort-based biochars $(p<0.05)$.

Beesley and Marmiroli (2011) reported that biochar can 300 -fold reduce $\mathrm{Cd}$ concentration and 45 -fold reduce $\mathrm{Zn}$ concentration in the leachate of contaminated soil. However, $\mathrm{Cd}$ and $\mathrm{Zn}$ can also be leached out from the biochar itself. In the current study, cadmium (Cd) leaching from SSC biochar was compared with that from plant-based biochar. A similar tendency was found as was the case with many other previously investigated elements. Cd concentration of SSC biochar was on average 9 times higher than of plant-based biochar. However, Cd leaching concentration was 16 times lower from SSC biochar than from plant-based biochar $(p<0.05)$ (Fig. 2).

Further research is required to determine why the leaching concentrations of PTEs from SSC biochar are lower or similar to those from plant-based biochar. It may be related to the $\mathrm{pH}$, Brunauer-Emmett-Teller (BET) surface area, pore structure or DOC values of the biochar itself (Agrafioti et al., 2013; Liang et al., 2017). High $\mathrm{pH}$ of SSC biochar can possibly reduce the mobility of PTEs thus inhibiting their leaching to the environment (Gusiatin et al., 2016; Liang et al., 2017).

According to this study, the $\mathrm{pH}$ of mugwortbased biochar was higher than that of SSC biochar $(p<0.05)$. However, Cd leaching from mugwort-based biochar was more intensive $(p<0.05)$. Beesley et al.
(2010) also noticed that it is difficult to elucidate all processes, which influence $\mathrm{Cd}$ and $\mathrm{Zn}$ mobility. In any case, it is important to note that high concentrations of PTEs in biochar do not necessarily result in high leaching concentrations of PTEs from that type of biochar. Conversely, low concentrations of PTEs in biochar do not prevent significant leaching of these elements from biochar. For example, in the case of plant-based biochar, the leaching percentage of $\mathrm{Cd}$ contained by it was $3.8 \%$ to $41.3 \%$; in the case of SSC biochar, the percentage was only $0.05 \%$ to $0.2 \% \mathrm{Cd}$ (Fig. 3). Also, it was found that Cd leaching was statistically lower for biochar produced from SSC-fertilized willow in comparison to biochar produced from SSC-fertilized mugwort $(p<0.05)$ (Fig. 2). In most cases, the fertilization of plants with SSC increased the Cd leaching concentrations from biochar based on these plants $(p<0.05)$.

Cd was the only investigated PTE that showed a decrease in leaching concentration of different types of biochar when temperature increased $(p<0.05)$. This happened because $\mathrm{Cd}$ is released from biochar to the environment during pyrolysis at $700^{\circ} \mathrm{C}$ (Van Wesenbeeck et al., 2014; Gusiatin et al., 2016). The leaching experiment showed that the increase in pyrolysis temperature usually decreased $\mathrm{Cd}$ leaching from biochar.

In summary, it was found that the leaching concentrations of $\mathrm{Pb}, \mathrm{Cr}$ and $\mathrm{Cu}$ were lower of willowbased biochar than those of mugwort-based biochar. The leaching concentrations of $\mathrm{Ni}$ and $\mathrm{Cd}$ were lower of the biochar produced from SSC-fertilized willow in comparison to the biochar produced from SSCfertilized mugwort. It was found also that in many cases the leaching of investigated PTEs was higher from the biochar produced from plants fertilized with SSC in comparison to the biochar based on unfertilized plants $(p<0.05)$. This means that biochar produced from unfertilized plants is more suitable for soil improvement.

The leaching percentage of $\mathrm{Pb}, \mathrm{Ni}, \mathrm{Cr}$ and $\mathrm{Cd}$ from plant-based biochar was high (3.8-50.1\%); however, it was low for $\mathrm{Cu}$ and $\mathrm{Zn}$ - only 0.076-2.89\% (Fig. 3). For all tested PTEs, leaching from SSC biochar as a percentage was much lower (only $0.012-2.75 \%$ ) than that from plantbased biochar. Also, although Agrafioti et al. (2013) reported that leaching of $\mathrm{Cr}, \mathrm{Ni}, \mathrm{Cd}, \mathrm{Cu}$ and $\mathrm{Pb}$ from sewage sludge biochar (pyrolysis at $300^{\circ} \mathrm{C}$ ) was only $0.1-4.0 \%$ (lower than $0.74 \mathrm{mg} \mathrm{kg}^{-1}$ ). Though, during the previous studies by the authors (Titova, Baltrènaitè-Gedienè, 2020; in press) PTEs concentrations in SSC-derived biochar were found to be above limit concentrations prescribed according to EBC (2012). As a result, SSC-derived biochar is not suitable for incorporation into the soil with the aim of improving its properties. It was not possible to identify any plant-derived biochar with the lowest leaching concentrations (\%) for all investigated PTEs (Fig. 3). The leaching of PTEs as a percentage was lower from the biochar produced at $700^{\circ} \mathrm{C}$ in comparison to produced at $450^{\circ} \mathrm{C}$. Only $\mathrm{Cd}$ showed the opposite trend $(p<0.05)$.

Modeling of forms of PTEs in eluates. Modeling with WHAM/Model VII (version for waters) showed that the increase in pyrolysis temperature can decrease the levels of PTEs in a free ion form in biochar eluates. This means that it can increase the levels of 
PTEs bound in complexes with DOC in biochar eluates. As a result, PTEs become less mobile and less toxic to microorganisms, plants, etc.

In the eluates of $\mathrm{SSC}$ biochar $\left(450^{\circ} \mathrm{C}\right.$ and $700^{\circ} \mathrm{C}$ ) and unfertilized willow- and mugwort-based biochar produced at $450^{\circ} \mathrm{C}$, PTEs were mostly in the form of free ions $(>0.8)$ (Fig. 4). This may be related to the fact that these eluates had the lowest $\mathrm{pH}$ from 7.8 to 9.2. The $\mathrm{pH}$ of the eluates of other types of biochar was from 9.8 to 11.3. In the eluates of biochar produced from SSC-fertilized mugwort and willow $\left(450^{\circ} \mathrm{C}\right)$ and from unfertilized and SSC-fertilized mugwort $\left(700^{\circ} \mathrm{C}\right)$, the levels of PTEs in the form of free ions were the lowest.

Modeling results showed that the elements that can be most often found in a free ion form $(>0.9)$ in the eluates of various types of biochar are $\mathrm{Cd}$ and Ni (Fig. 4). It is likely that the free ion form of $\mathrm{Cr}$ is very rare in the eluates of all types of biochar. In other words, it is assumed that the majority of $\mathrm{Cr}$ leached from biochar will be bound to DOC (Tipping et al., 2011). Based on the analysis of results obtained by modeling the forms of elements in the eluate, it is recommended using mugwort-based biochar $\left(700^{\circ} \mathrm{C}\right)$ as a soil amendment, because it has the lowest part of PTEs in a free ion form in its eluates.

Physical and chemical properties of biochar. In order to better understand, which type of biochar is most suitable for soil improvement, the cation exchange capacity (CEC) and hydrophobicity of biochar were investigated. The biochar produced at $700^{\circ} \mathrm{C}$ was found to have a statistically significantly higher CEC (42.6$\left.66.9 \mathrm{cmol} \mathrm{kg}^{-1}\right)$ compared to that produced at $450^{\circ} \mathrm{C}$ (32.4-63.6 cmol kg-1) $(p<0.05)$ (Fig. 5). Gusiatin et al. (2016) studied the biochar produced from maize silage, sewage sludge compost, wooden pellets and digestate residues (pyrolysis at $300^{\circ} \mathrm{C}$ and $600^{\circ} \mathrm{C}$ ). They found that not always at higher pyrolysis temperatures the $\mathrm{CEC}$ of biochar was higher. It was also found that the mugwort-based biochar exhibited a higher CEC (53.4$\left.66.9 \mathrm{cmol} \mathrm{kg}^{-1}\right)$ compared to the willow-based biochar $\left(34.8-43.2 \mathrm{cmol} \mathrm{kg}^{-1}\right)(p<0.05)$.

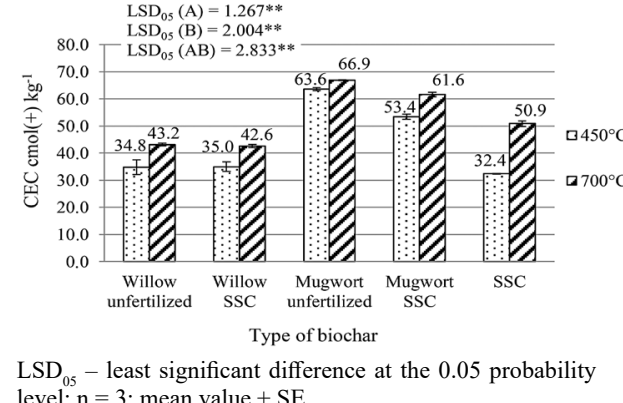
level; $\mathrm{n}=3 ;$ mean value $\pm \mathrm{SE}$

SSC - sewage sludge compost

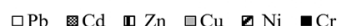

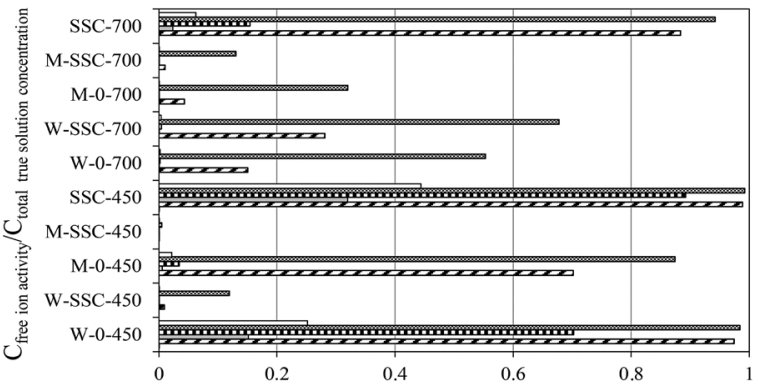

Eluates of biochar, produced from: SSC-450 and SSC-700 - sewage sludge compost (SSC), W-0-450 and W-0-700 - unfertilized willow, W-SSC-450 and W-SSC-700 - willow fertilized with SSC, $\mathrm{M}-0-450$ and M-0-700 - unfertilized mugwort, M-SSC-450 and M-SSC-700 - mugwort fertilized with SSC

Figure 4. Part of potentially toxic elements (PTEs) that is in the eluates in a free ion form

The biochar with higher CEC is more useful for soil quality improvement. The higher the CEC, the more pollutants (including PTEs) can be adsorbed by biochar from the soil (Gusiatin et al., 2016). In addition, the higher the CEC concentration in biochar, the more biochar can retain the nutrients needed by plants from soil. As a result, nutrients will be retained and not leached to groundwater. Plants will then be able to use these nutrients. This fact is particularly important in light-textured soils where nutrient leaching is a very common problem.

The hydrophobicity of different types of biochar was also investigated during the experiment. The results are shown in Figure 5. SSC biochar was found to be more hydrophilic compared to the biochar produced from the studied plants. The willow-based biochar was slightly more hydrophilic compared to the biochar produced from mugwort. The biochar produced at $700^{\circ} \mathrm{C}$

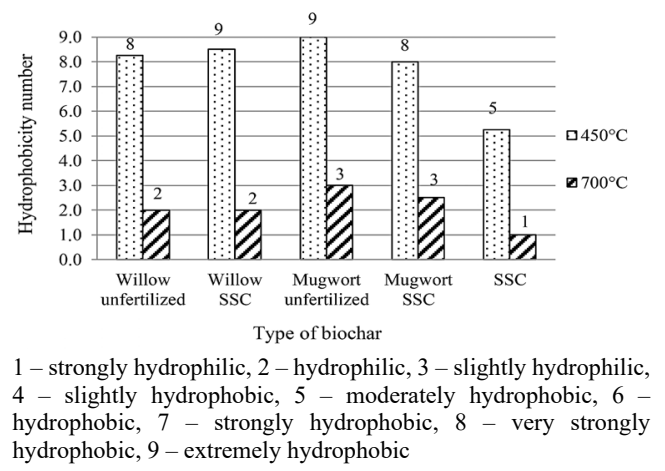

Figure 5. Cation exchange capacity (CEC) and hydrophobicity of different biochar types

was more hydrophilic than that produced at $450^{\circ} \mathrm{C}$. The tendency of decreasing hydrophobicity with increasing pyrolysis temperature was also found by Usevičiūte and Baltrenaite (2019). The less hydrophobic the biochar is, the more water it can retain, which is also very important when we plan to use biochar for improvement of lighttextured soils.

The analysis of CEC and hydrophobicity confirmed the results of previous studies by the authors (Titova, Baltènaitè-Gedienè, 2020; in press): the biochar produced at $700^{\circ} \mathrm{C}$ is more suitable for soil improvement. However, it is difficult to decide, which plant's biochar is more suitable for incorporation into the soil with the aim of improving its properties.

\section{Conclusions}

1. The concentrations of $\mathrm{Pb}, \mathrm{Ni}, \mathrm{Cr}, \mathrm{Cu}, \mathrm{Zn}$ and $\mathrm{Cd}$ leached from the biochar were not directly proportional to the initial total concentrations of these elements contained in the biochar.

2. The leaching of potentially toxic elements (PTEs) was higher from the biochar produced from plants fertilized with sewage sludge compost (SSC) in comparison to the biochar produced from unfertilized plants $(p<0.05)$.

3. In most cases, the leaching concentrations of PTEs were lower of willow-based biochar in comparison to mugwort-based biochar. However, in the eluates of mugwort-based biochar, the part of PTEs in the form of free ions was the lowest. 
4. No single trend showing the impact of pyrolysis temperature on the leaching of investigated PTEs from biochar was found. However, modeling results showed that the increase in pyrolysis temperature can decrease the part of PTEs in a free ion form in biochar eluates.

5 . The highest cation exchange capacity (CEC) was observed in mugwort-based biochar (pyrolysis was performed at $700^{\circ} \mathrm{C}$ ). More hydrophilic was biochar produced at $700^{\circ} \mathrm{C}$.

6. Based on the analysis of all data, biochar from unfertilized plants (pyrolysis at $700^{\circ} \mathrm{C}$ ) would be most suitable for use in soil improvement.

\section{Acknowledgements}

This project has received funding from European Social Fund (project No. 09.3.3-LMT-K-712-02-0030) under grant agreement with the Research Council of Lithuania (LMTLT).

Received 29112019

Accepted 30042020

\section{References}

1. Agrafioti E., Bouras G., Kalderis D., Diamadopoulos E. 2013. Biochar production by sewage sludge pyrolysis. Journal of Analytical and Applied Pyrolysis, 101: 72-78. https://doi.org/10.1016/j.jaap.2013.02.010

2. Bakšienè E., Titova J 2018. Effects of cultivation technologies on woody biomass yield of various willow (Salix spp.) cultivars. Zemdirbyste-Agriculture, 105 (4) 339-348. https://doi.org/10.13080/z-a.2018.105.043

3. Beesley L. Marmiroli M. 2011. The immobilisation and retention of soluble arsenic, cadmium and zinc by biochar. Environmental Pollution, 159: 474-480. https://doi.org/10.1016/j.envpol.2010.10.016

4. Beesley L., Moreno-Jimenez E., Gomez-Eyles J. L. 2010. Effects of biochar and greenwaste compost amendment on mobility, bioavailability and toxicity of inorganic and organic contaminants in a multi-element polluted soil Environmental Pollution, 158: 2282-2287.

https://doi.org/10.1016/j.envpol.2010.02003

5. Chan K. Y., Van Zwieten L., Meszaros I., Downie A., Joseph S. 2007. Agronomic values of greenwaste biochar as a soil amendment. Australian Journal of Soil Research, 45: 629-634. https://doi.org/10.1071/SR07109

6. Demo M., Hauptvogl M., Prčik M., Huska D. 2014 Comparison of production parameters of willow (Salix spp.) and poplar (Populus spp.) varieties in the last year of the first four-year harvest cycle. Wood Research, 59 (4): 705-715.

7. Dimitriou I., Mola-Yudego B., Aronsson P., Eriksson J. 2012. Changes in organic carbon and trace elements in the soil of willow short-rotation coppice plantations. BioEnergy Research, 5 (3): 563-572.

https://doi.org/10.1007/s12155-012-9215-1

8. Doerr S. H. 1998. On standardizing the 'Water drop penetration time' and the 'Molarity of an ethanol droplet' techniques to classify soil hydrophobicity: a case study using medium textured soils. Earth Surface Processes and Landforms, 23 (7): 663-668.

https://doi.org/10.1002/(SICI)1096-

9837(199807) 23:7<663::AID-ESP909>3.0.CO $2-6$

9. EBC. 2012. European Biochar Certificate. Guidelines for a Sustainable Production of Biochar. European Biochar Foundation. http://www.europeanbiochar.org/en/ download

10. Frenkel O., Jaiswal A. K., Elad Y., Lew B., Kammann C. Graber E. R. 2017. The effect of biochar on plant diseases what should we learn while designing biochar substrates? Journal of Environmental Engineering and Landscape Management, 25 (2): 105-113.

https://doi.org/10.3846/16486897.2017.1307202

11. Grignet A., de Vaufleury A., Papin A., Bert V. 2020. Urban soil phytomanagement for $\mathrm{Zn}$ and $\mathrm{Cd}$ in situ removal, greening, and Zn-rich biomass production taking care of snail exposure. Environmental Science and Pollution Research, 27: 3187-3201 https://doi.org/10.1007/s11356-019-06796-2

12. Gusiatin Z. M., Kurkowski R., Brym S., Wiśniewski D. 2016. Properties of biochars from conventional and alternative feedstocks and their suitability for metal immobilization in industrial soil. Environmental Science and Pollution Research, 23 (21): 21249-21261. https://doi.org/10.1007/s11356-016-7335-4
13. Haider G., Steffens D., Müller C., Kammann C. I. 2016. Standard extraction methods may underestimate nitrate stocks captured by field-aged biochar, Journal of Environmental Quality, 45 (4): 1196-1204. https://doi.org/10.2134/jeq2015.10.0529

14. IBI. 2014. International Biochar Initiative. Standardized product definition and product testing guidelines for biochar that is used in soil (Aka IBI biochar standards). IBISTD-1.1. https://www.biocharinternational.org/wp-content/ uploads/2018/04/IBI Biochar Standards V2.1 Final.pdf

15. Jama-Rodzeńska A., Nowak W. 2012. Nickēl and lead uptake by willows (Salix viminalis L.). Polish Journal of Agronomy, 11: 29-33

16. Kacprzak M., Neczaj E., Fijałkowski K., Grobelak A., Grosser A., Worwag M., Rorat A., Brattebo H., Almås A., Singh B. R. 2017. Sewage sludge disposal strategies for sustainable development. Environmental Research, 156: 39-46. https://doi.org/10.1016/j.envres.2017.03.010

17. Kadžiulienè Z., Tilvikienė V., Liaudanskienè I., Pocienė L., Cerniauskienè Z., Zvicevicius E., Raila, A. 2017. Artemisia dubia growth, yield and biomass characteristics for combustion. Zemdirbyste-Agriculture, 104 (2): 99-106. https://doi.org/10.13080/z-a.2017.104.013

18. Kammann C. I., Schmidt H.-P., Messerschmidt N., Linsel S., Steffens D., Müller C., Koyro H.-W., Conte P., Joseph S. 2015. Plant growth improvement mediated by nitrate capture in co-composted biochar. Scientific Reports, 5: 11080. https://doi.org/10.1038/srep12378

19. Kryževičiene A., Sarūnaitè L., Stukonis V., Dabkevičius Z., Kadžiulienė Z. 2010. Daugiamečiu kiečiu (Artemisia vulgaris L. ir Artemisia dubia Wall.) potencialo biokuro gamybai ivertinimas. Zemès ūkio mokslai, 17 (1-2) 32-40 (in Lithuanian).

20. Krzyżaniak M., Stolarski M. J. Waliszewska B. Szczukowski S., Tworkowski J., Załuski D., Snieg M. 2014. Willow biomass as feedstock for an integrated multiproduct biorefinery. Industrial Crops and Products, 58 230-237. https://doi.org/10.1016/j.indcrop.2014.04.033

21. Laird D., Fleming P., Wang B., Horton R. Karlen D. 2010. Biochar impact on nutrient leaching from a Midwestern agricultural soil. Geoderma, 158: 436-442 https://doi.org/10.1016/j.geoderma.2010.05.012

22. Laird D. A., Rogovska N. P. 2015. Biochar effects on nutrient leaching. Lehmann J., Joseph S. (eds). Biochar for environmental management - science, technology and implementation. Chapter 18, p. 519-540.

23. Liang J., Yang Z., Tang L., Zeng G., Yu M., Li X., Wu H., Qian Y., Li X., Luo Y. 2017. Changes in heavy metal mobility and availability from contaminated wetland soil remediated with combined biochar-compost. Chemosphere, 181: 281-288. https://doi.org/10.1016/j.chemosphere.2017.04.081

24. Lu H., Zhang W., Wang S., Zhuang L., Yang Y., Qiu R. 2013. Characterization of sewage sludge-derived biochars from different feedstocks and pyrolysis temperatures. Journal of Analytical and Applied Pyrolysis, 102: 137-143. https://doi.org/10.1016/j.jaap.2013.03.004

25. Mancinelli E., Baltrenaite E., Baltrènas P., Paliulis D. Passerini G. 2016. Trace metals in biochars from biodegradable by-products of industrial processes. Water, Air, and Soil Pollution, 227 (6): 198. https://doi.org/10.1007/s11270-016-2892-1

26. Mancinelli E., Baltrènaitė E., Baltrènas P., Marčiulaitienė E. Passerini G. 2017. Dissolved organic carbon content and leachability of biomass waste biochar for trace metal (Cd $\mathrm{Cu}$ and $\mathrm{Pb}$ ) speciation modelling. Journal of Environmental Engineering and Landscape Management, 25 (4): 354-366. https://doi.org/10.3846/16486897.2017.1339047

27. Mola-Yudego B., Gonzáles-Olabarria J.-R. 2010. Mapping the expansion and distribution of willow plantations for bioenergy in Sweden: lessons to be learned about the spread of energy crops. Biomass and Bioenergy, 34 (4): 442-448. https://doi.org/10.1016/j.biombioe.2009.12.008

28. Munera-Echeverri J. L., Martinsena V., Stranda L. T., Zivanovic V., Cornelissena G., Mulder J. 2018. Cation exchange capacity of biochar: an urgent method modification. Science of the Total Environment, 642: 190-197. https://doi.org/10.1016/j.scitotenv.2018.06.017

29. Nasr M. 2020. Phytomanagement in Egypt: a sustainable approach for clean environment coupled with meeting future energy demand. Negm A., Shareef N. (eds). Waste management in MENA regions. Springer, p. 93-109. https://doi.org/10.1007/978-3-030-18350-9_5

30. Njakou Djomo S., Zenone A.T., De Groote T., Bergante S., Facciotto G., Sixto H., Ciria Ciria P., Weger J., Ceulemans R. 2015. Energy performances of intensive and extensive short rotation cropping systems for woody biomass production in the EU. Renewable and Sustainable Energy Reviews, 41: 845-854.

https://doi.org/10.1016/j.rser.2014.08.058 
31. Novotny E. H., Maia C. M. B. de F., Carvalho M. T. de M., Madari B. E. 2015. Biochar: pyrogenic carbon for agricultural use - a critical review. Revista Brasileira de Ciência do Solo, 39 (2): 321-344. https://doi.org/10.1590/01000683rbes20140818

32. Ozdemir S., Turp S. M., Oz N. 2020. Simultaneous drysorption of heavy metals by porous adsorbents during sludge composting. Environmental Engineering Research, 25 (2): 258-265. https://doi.org/10.4491/eer.2019.071

33. Pečkytė J., Baltrènaitė E. 2015. Assessment of heavy metals leaching from (bio)char obtained from industrial sewage sludge. Science - Future of Lithuania, 7 (4): 399406. https://doi.org/10.3846/mla.2015.811

34. Rasa K., Heikkinen J., Hannula M., Arstila K., Kulju S., Hyväluoma J. 2018. How and why does willow biochar increase a clay soil water retention capacity? Biomass and Bioenergy, 119: 346-353. https://doi.org/10.1016/j.biombioe.2018.10.004

35. Sakalauskas A., Jasinskas A., Šarauskis E, Vaiciukevičius E., Kalinauskaitè S., Simonaitis P. 2012. Žemès ūkio, maisto ūkio ir žuvininkystès MTTV projekto „Augalinès biomasès (šiaudu, žaliu, isimedejusiụ augalu ir kt.) nuemimo ir paruošimo biokurui dispergavimo būdu technologijos pagrindimas" baigiamoji ataskaita. Aleksandras Stulginskis University, p. 5-84 (in Lithuanian).

36. Shareef T., Zhao B. 2017. Review paper: the fundamentals of biochar as a soil amendment tool and management in agriculture scope: an overview for farmers and gardeners. Journal of Agricultural Chemistry and Environment, 6 (1): 38-61. https://doi.org/10.4236/jacen.2017.61003

37. Song J., He Q., Hu X., Zhang W., Wang C., Chen R., Wang H., Mosa A. 2019. Highly efficient removal of $\mathrm{Cr}(\mathrm{VI})$ and $\mathrm{Cu}(\mathrm{II})$ by biochar derived from Artemisia argyi stem. Environmental Science and Pollution Research, 26 (13): 13221-13234

https://doi.org/10.1007/s11356-019-04863-2

38. Tammeorg P., Bastos A. C., Jeffery S., Rees F., Kern J., Graber E. R., Ventura M., Kibblewhite M., Amaro A., Budai A., Cordovil C. M. d. S., Domene X., Gardi C., Gascó G., Horák J., Kammann C., Kondrlova E., Laird D., Loureiro S., Martins M. A. S., Panzacchi P., Prasad M., Prodana M., Puga A. P., Ruysschaert G., Sas-Paszt L., Silva F. C., Teixeira W. G., Tonon G., Vedove G. D. Zavalloni 'C., Glaser B., Verheijen F. G. A. 2017. Biochars in soils: towards the required level of scientific understanding. Journal of Environmental Engineering and Landscape Management, 25 (2): 192-207.

https://doi.org/10.3846/16486897.2016.1239582

39. The productivity of Lithuania's land / compiled by Mažvila J. 2011. Lithuanian Research Centre for Agriculture and Forestry, 280 p. (in Lithuanian).

40. Tipping E., Lofts S., Sonke J. 2011. Humic ion-binding model VII: a revised parameterisation of cation-binding by humic substances. Environmental Chemistry, 8: 225-235. https://doi.org/10.1071/EN11016

41. Titova J. 2016. Influence of fertilization with sewage sludge compost on biomass formation of energy plants and changes of chemical elements: doctoral dissertation. Lithuanian Research Centre for Agriculture and Forestry, 159 p. (in Lithuanian).

42. Titova J., Bakšienè E. 2015. The influence of sewage sludge compost on the growth of energy plants mugwort (Artemisia dubia Wall.) and Virginia fanpetals (Sida hermaphrodita (L.) Rusby). Žemès ūkio mokslai / Agricultural Sciences, 22 (3): 155-162 (in Lithuanian). https://doi.org/10.6001/zemesukiomokslai.v22i3.3156

43. Titova J., Baltrénaite-Gediené E. 2020. Physical and chemical properties of biochar produced from sewage sludge compost and plants biomass, fertilized with that compost, important for soil improvement. Waste and Biomass Valorization (in press).

44. Usevičiūtè L., Baltrènaitè E. 2019. Methods for determining lignocellulosic biochar wettability. Waste and Biomass Valorization. https://doi.org/10.1007/s12649-019-00713-x

45. Van Wesenbeeck S., Prins W., Ronsse F., Antal Jr. M. J. 2014. Sewage sludge carbonization for biochar applications. Fate of heavy metals. Energy Fuels, 28 (8): 5318-5326. https://doi.org/10.1021/ef500875c

46. Wierzbowska J., Sienkiewicz S., Krzebietke S., Sternik P. 2016. Sewage sludge as source of nitrogen and phosphorus for Virginia fanpetals. Bulgarian Journal of Agricultural Science, 22 (5): 722-727.

47. WRB. 2014. World reference base for soil resources. World Soil Resources Reports No. 106. FAO, p. 187-189.

48. Zhao B., O'Connor D., Zhang J., Peng T., Shen Z., Tsang D.C.W., Hou D. 2018. Effect of pyrolysis temperature, heating rate, and residence time on rapeseed stem derived biochar. Journal of Cleaner Production, 174: 977-987. https://doi.org/10.1016/j.jclepro.2017.11.013

ISSN 1392-3196 / e-ISSN 2335-8947

Zemdirbyste-Agriculture, vol. 107, No. 3 (2020), p. 235-242

DOI $10.13080 / z-a .2020 .107 .030$

\title{
Potencialiai toksiškų elementų išplovimas iš dirvožemiui pagerinti skirtos bioanglies
}

\author{
J. Titova ${ }^{1}$, E. Baltrènaitè-Gedienè ${ }^{1}$, A. Medyńska-Juraszek ${ }^{2}$, E. Bakšienė ${ }^{3}$ \\ ${ }^{1}$ Vilniaus Gedimino technikos universiteto Aplinkos apsaugos institutas \\ ${ }^{2}$ Vroclavo aplinkos ir gyvosios gamtos mokslu universiteto \\ Dirvožemio mokslo ir aplinkos apsaugos institutas, Lenkija \\ ${ }^{3}$ Lietuvos agrarinių ir miškų mokslų centro Vokès filialas
}

\section{Santrauka}

Tirta žaliavos tipo ir pirolizės temperatūros įtaka potencialiai toksiškų elementų (PTE): $\mathrm{Cu}, \mathrm{Zn}, \mathrm{Cd}, \mathrm{Ni}, \mathrm{Cr}$ ir Pb, išplovimui iš bioanglies. Tyrimo tikslas - nustatyti, koks bioanglies tipas būtu tinkamiausias dirvožemiui gerinti. Naudotos penkiu rūšiu žaliavos: nuoteku dumblo kompostas (1), veislès 'Tora' netręštu (2) ir tręštų nuoteku dumblo kompostu (3) gluosnių (Salix sp.) biomase, netręštų (4) ir tręštų nuotekų dumblo kompostu (5) pavèsinių kiečių (Artemisia dubia Wall.) biomasè.

Nustatyta, kad iš kiečių bioanglies išplautos didesnès PTE koncentracijos nei iš gluosnių bioanglies. Tačiau kiečių bioanglies eliuatuose buvo didžiausia PTE dalis, kuri buvo komplekse su ištirpusia organine anglimi. Tai reiškia, kad PTE kiečių eliuatuose buvo mažiau judrūs ir toksiški dirvožemio organizmamams. PTE, kurie buvo išplauti iš bioanglies, pagamintos $700^{\circ} \mathrm{C}$ temperatūroje, taip pat daugiausia buvo komplekse su ištirpusia organine anglimi. Iš bioanglies, pagamintos iš nuotekų dumblo kompostu tręštų augalų, išplautos didesnès PTE koncentracijos nei iš pagamintos iš netręštu augalų bioanglies.

Nèra duomenų, kaip vyktų PTE išplovimo iš bioanglies procesas, jei ši bioanglis būtų ịterpta ị dirvožemį. Tam įtakos gali turèti daugelis veiksnių. Nustatyta, kad bioanglies PTE išplovimo koncentracijos ne visada tiesiogiai priklausė nuo suminių šioje bioanglyje esančių PTE koncentracijų; tačiau dirvožemiui pagerinti galbūt labiau tiktų netręštų augalų bioanglis, pagaminta $700^{\circ} \mathrm{C}$ temperatūroje.

Reikšminiai žodžiai: Artemisia dubia, nuotekų dumblo kompostas, potencialiai toksiški elementai, Salix, sunkieji metalai. 